\title{
Detection and Identification of Eimeria species in Naturally Infected Calves at Assiut Governorate Safaa S. Malek ${ }^{1}$ and Huda M. Kuraa ${ }^{2 *}$ \\ ${ }^{1}$ Animal Medicine Department (Infectious Diseases), Faculty of Veterinary Medicine, Assiut University \\ ${ }^{2}$ Animal Health Research Institute, Assiut Laboratory \\ Article History: Received: 7/2/2018 Received in revised form: 22/2/2018 Accepted: 26/2/2018
}

\begin{abstract}
The current study was carried out to investigate the prevalence of Eimeria species among 75 diarrheic calves in Assiut Governorate. Oocysts of Eimeria spp. were found in 46.7\% (35/75) of the examined fecal samples from diarrheic calves using light microscope and $88 \%(22 / 25)$ by using PCR. Very high significant difference of Eimeria infection was recorded in calves 3-6 months of age, $73.3 \%(22 / 30)$ and 1 week-3 months of age $28.9 \%(13 / 45)$. The prevalence of Eimeria spp. in calves with diarrhea showed the highest rate in summer $(69.2 \%)$, followed by winter (36.4\%), autumn (25\%) and spring (7.7\%). Eight species of Eimeria were isolated by parasitological examination. The prevalence of Eimeria spp. was E. zuernii (51.4\%) followed by E. bovis (31.4\%), E. alabamensis (31.4\%), E. cylindrica (25.7\%), E. subspherica (14.3\%), E. canadensis (11.4\%), E. ellipsoidalis (5.7\%) and E. auburnensis (2.9\%). Single infection of Eimeria spp. was found in $48.6 \%$ of the infected calves, whereas mixed infection involved two, three or four Eimeria spp. was observed in 51.4\% of the infected calves. In conclusion, season and age of the calves were the most significant aspects connected with the possibility of infection with coccidiosis The PCR is a more reliable, sensitive and less time-consuming approach for diagnosis of Eimeria.
\end{abstract}

Keywords: Eimeria species, PCR, Naturally Infected, Calves.

\section{Introduction}

Bovines are one of the main source of meat production in Egypt, they are generally reared in small owner farms and suffer from malnutrition and parasitism [1]. The most important cause of calf morbidity and mortality is diarrhea [2]. Neonatal calf diarrhea (NCD) continues to be the first reason of calf mortality in Egypt; with an estimated $27.4-55 \%$ of the total deaths in young calves [3].

Neonatal calf diarrhea is caused by various infectious agents such as viruses, bacteria and protozoa [4]. The disease leads to economic losses in cattle flocks all over the world [5]. These losses are attributable to decreased growth rates, treatment costs and time spent caring for the affected calves [6,7]. Infectious agents may cause initial damage to the intestine, while death from scours usually results from dehydration, acidosis and loss of electrolytes. Determination of enteropathogens causing scours is necessary for performance of effective prevention and treatment [8]. Coccidia is as an important cause of diarrhea in calves, and is associated with other enteropathogens $[9,10]$.

Bovine coccidiosis is an important disease of apicomplexan parasites of genus Eimeria and is one of the main vital and common diseases of cattle worldwide [11]. It is considered one of the five most economically important diseases in the cattle industry [12]. The greatest economic losses are usually caused by acute diarrhea which accounts for approximately $75 \%$ of the mortality losses [13]. The highest prevalence of the disease takes place in calves less than one year of age [14]. All calves reared in conventional systems are exposed to coccidia and can be infected early in life [15].

Eimeria spp. are strictly host specific, and more than 20 species of Eimeria are defined in cattle [14,16]. Eimeria bovis and Eimeria zuernii are most commonly pathogenic species in calves worldwide causing morbidity and mortality by disturbing intestinal absorption and often associated with diarrheic feces which contain blood, fibrin and intestinal tissues $[14,17,18]$.

\footnotetext{
*Corresponding author e-mail: (huda5380@yahoo.com), Animal Health Research Institute, Assiut
} 
The progress of clinical coccidiosis in cattle mainly depends on many factors such as the species of Eimeria, age of infected animal, number of ingested oocysts and breeding system; besides the management practices $[14,19]$. Relying on temperature, moisture and other ecological factors, sporulation of oocysts occurs within a week and the sporulated oocysts become infective and sustain their infectivity for several months under favorable environmental conditions such as temperature and moisture. The sporulated oocyst has four sporocysts each one contains two sporozoites [20].

The only practical way to recognize bovine Eimeria spp. is the detection of oocysts' morphology [14]. Nevertheless, the morphology of oocysts is not completely efficient as numerous Eimeria spp. have confusing features beside its intraspecies dissimilarity [21]. In addition, fecal inspection in conjunction with morphological identification is very intensive work which requires skilled method. Detection and differentiation of Eimeria by PCR showed higher sensitivity than the conventional identification of oocysts and is considered a useful technique for diagnosis of bovine coccidial infection [22].

Therefore, the present study aimed to determine the prevalence of Eimeria species infecting calves and its identification using oocysts morphological features and PCR assay in Assiut Governorate.

\section{Materials and Methods}

\section{Animals and sample collection}

A total of 75 fecal samples were collected from diarrheic calves from May 2016 to July 2017 in Assiut Governorate. The calves were categorized according to age into two groups: 1 week - 3 months and 3-6 months [23]. The date of sampling, the age and season were recorded for each calf. Thirty grams of feces were collected directly from the rectum using sterile gloves in dry and clean plastic bottles. The fecal samples were transferred immediately to the laboratory and were kept at $4^{\circ} \mathrm{C}$ in a refrigerator until processing within 48 $\mathrm{h}$ of arrival.

\section{Parasitological examination}

Microscopic fecal examinations were done for the detection of oocysts by direct smear and concentration flotation technique using saturated salt solution [24].

\section{Sporulation of Eimeria spp. oocysts}

The oocysts in positive fecal samples were sporulated using $2.5 \%$ potassium dichromate solution, aired frequently by using a pipette and left at room temperature before investigating by light microscope [24,25]. The size of non sporulated oocysts and sporulated oocysts was measured using light microscope with a calibrated eye piece micrometer and the Eimeria species were identified according to their size, shape, color and other morphological features such as micropyle, micropyle cap, shape of sporocyst, steida body and residual bodies [24].

\section{Polymerase Chain Reaction (PCR)}

Twenty-five fecal samples from calves (20 positive and 5 negative for Eimeria spp. by microscopic examination) were tested with PCR assay.

\section{DNA extraction procedures}

DNA was extracted using Bioline ISOLATE Fecal DNA Kit 50 Preps Cat No. BIO-52082, Lot No. IS674-114B according to the instructions of manufacturer. DNA was stored at $-20^{\circ} \mathrm{C}$ till used.

\section{PCR assays with Eimeria-common primers}

Primers were manufactured by Metabion international (Germany). The up-and downstream primer sequences of Eimeriacommon sequence in internal transcribed spacer 1 (ITS-1) region were: F: 5'- GCA AAA GTC GTA ACA CGG TTT CCG -3’' R: 5'- CTG CAA TTC ACA ATG CGT ATC GC-3' with expected product sizes of 348-546 bp. A volume of $20 \mu \mathrm{L}$ of reaction mixture comprised of $10 \mu \mathrm{L}$ MyTaq $^{\mathrm{TM}}$ HS Red Mix (Bioline, lot no. MTHRX-516201), $1 \mu \mathrm{L}$ of the $10 \mu \mathrm{M}$ primer $(0.5 \mu \mathrm{M}$ each $)$ and $1 \mu \mathrm{L}$ of extracted DNA. Reaction conditions included an initial denaturing phase at $94^{\circ} \mathrm{C}$ for $30 \mathrm{sec}$ followed by 35 cycles at $94^{\circ} \mathrm{C}$ for $10 \mathrm{sec}, 55^{\circ} \mathrm{C}$ for $20 \mathrm{sec}, 72^{\circ} \mathrm{C}$ for $20 \mathrm{sec}$ with final extension at $72^{\circ} \mathrm{C}$ for $2 \mathrm{~min}$ by Applied Biosystems Veriti Thermal Cycler 9902 (Singapore) [22]. 
PCR assays with species-specific primer

Primers were manufactured by Metabion international (Germany). The up-and downstream primer sequences of Eimeria bovis were: F: 5'-TCA TAA AAC ATC ACC TCC AA-3', R: 5'-ATA ATT GCG ATA AGG GAG ACA-3' with expected product size 238 (bp). Primer sequences of Eimeria zuernii were: F: 5'-AAC ATG TTT CTA CCC ACT AC-3', R: 5'-CGA TAA GGA GGA GGA CAA C-3' with expected product size $344 \mathrm{bp}$ [22]. The reaction conditions of both $E$. bovis and E. zuernii are similar to ITS-1 PCR. The PCR conditions for E. bovis included an initial denaturing phase at $94^{\circ} \mathrm{C}$ for $30 \mathrm{sec}$ followed by 35 cycles which at $94^{\circ} \mathrm{C}$ for 10 $\mathrm{sec}, 55^{\circ} \mathrm{C}$ for $20 \mathrm{sec}, 72^{\circ} \mathrm{C}$ for $20 \mathrm{sec}$ with final extension at $72^{\circ} \mathrm{C}$ for $2 \mathrm{~min}$. While for $E$. zuernii for the reaction conditions included an initial denaturing phase at $94^{\circ} \mathrm{C}$ for $30 \mathrm{sec}$ followed by 35 cycles which at $94^{\circ} \mathrm{C}$ for 10 sec, $52^{\circ} \mathrm{C}$ for $20 \mathrm{sec}, 72^{\circ} \mathrm{C}$ for $20 \mathrm{sec}$ and final extension at $72^{\circ} \mathrm{C}$ for $2 \mathrm{~min}$. Then, $10 \mu \mathrm{L}$ of PCR products were electrophoresed in $1.5 \%$ agarose gel (Bioshop ® Canada Inc., Burlington, ON. L7L 6A4) with 100 bp DNA ladder (Biomatik, code: M7123) and the amplified products were visualized using UV transilluminator.

\section{Statistical analysis}

Chi- square test was used to compare the prevalence of Eimeria spp. among investigated calves according to age and season [26].

\section{Results}

Oocysts of Eimeria spp. were found in $46.7 \%(35 / 75)$ of the examined fecal samples from diarrheic calves using light microscope and found in $88 \%(22 / 25)$ of the examined fecal samples by PCR. The overall prevalence of Eimeria spp. according to age was higher in calves of 3 - 6 months age $(73.3 \%)$ than that in calves of 1 week -3 months age $(28.9 \%)$. Very high significant difference of Eimeria spp. was recorded between the two groups $(\mathrm{P}<0.001)$. Concerning the season, very high significant difference in Eimeria spp. prevalence of diarrheic calves in summer $(69.2 \%)$ followed by winter $(36.4 \%)$, autumn (25\%) and spring (7.7\%) (Table 1).

Parasitological examination revealed that the isolated eight species of Eimeria in calves were E. zuernii, E. bovis, E. alabamensis, E. cylindrica, E. subspherica, E. canadensis, E. ellipsoidalis and E. auburnensis. The percentages of Eimeria spp. infecting calves were E. zuernii (51.4\%) followed by E. bovis $(31.4 \%), \quad E$. alabamensis $(31.4 \%), \quad E$. cylindrica (25.7\%), E. subspherica (14.3\%), E. canadensis (11.4\%), E. ellipsoidalis (5.7\%) and E. auburnensis (2.9\%), (Figures 1, 2 and Table 2). Single infection of Eimeria spp. was found in $48.6 \%(17 / 35)$ of the infected animals, whereas mixed infection involved two, three or four Eimeria spp. was observed in $51.4 \%(18 / 35)$ of the infected animals.

Table 1: Effect of age and season on the prevalence of infection in the examined calves (\%) using light microscope

Age/Season No. of examined calves No. of positive samples $\%$ 1 week - 3 month 45 13 28.9

Age 3-6 month 30 $22 *$ 73.3

\begin{tabular}{|c|c|c|c|c|}
\hline & $3-6$ month & 30 & $22 *$ & 73.3 \\
\hline \multirow{3}{*}{ Season } & Winter & 11 & 4 & 36.4 \\
\hline & Summer & 39 & $27 *$ & 69.2 \\
\hline & Spring & 13 & 1 & 7.7 \\
\hline & Autumn & 12 & 3 & 25 \\
\hline
\end{tabular}

\footnotetext{
* High significant differences $(\mathrm{P}<0.001)$
} 
Table 2: Morphological features of different Eimeria spp. isolated from naturally infected calves $(\mathbf{n}=35)$

\begin{tabular}{lccccc}
\hline Eimeria species & $\begin{array}{c}\text { No. of infected } \\
\text { calves }\end{array}$ & $\%$ & Shape & Size um & Micropyle \\
\hline E. subspherica & 5 & 14.3 & Subspherical & $11.7 \times 11 \mu$ & No \\
E. zuernii & 18 & 51.4 & Spherical & $18.8 \times 17.9 \mu$ & No \\
E. bovis & 11 & 31.4 & Ovoidal & $25.4 \times 17.2 \mu \mathrm{m}$ & Present \\
E. cylindrical & 9 & 25.7 & Cylindrical & $22.3 \times 12.6 \mu$ & No \\
E. alabamensis & 11 & 31.4 & Subcylindrical & $20.8 \times 13.6 \mu$ & No \\
E. elipsoidalis & 2 & 5.7 & Ellipsiodal & $17.2 \times 12.4 \mu$ & No \\
E. canadinensis & 4 & 11.4 & Ellipsoidal & $29.4 X 20.3 \mu$ & Present \\
E. auburnensis & 1 & 2.9 & Ellipsiodal to tapering & $33.9 \times 20 \mu$ & Present \\
\hline
\end{tabular}

Molecular examination of 25 samples (20 positive and 5 negative by microscopical examination) by ITS-1 PCR revealed that all 20 positive samples by microscopical examination were positive by PCR, while 2 negative samples by microscopical examination were positive by PCR (Figure 3A). Further, the samples were examined by species-specific primers for E. zuernii and $E$. bovis. Out of the twenty samples positive by microscopy, five samples were identified as $E$. bovis by microscopical examination, while, 6 were positive by PCR (Figure 3B). Moreover, 8 were identified as E. zuernii, while PCR identifies 9 samples using the specific primers of E. zuernii (Figure 3C).

\section{Discussion}

Coccidiosis causes great economic losses for cattle as a result of decrease in feed efficiency which leads to slow weight gain and increased predisposition to other diseases [27]. There are no sufficient records about coccidiosis in calves in Assiut; therefore, our study was planned to throw light on calves' coccidiosis.

Our results indicated that 35 out of 75 $(46.7 \%)$ examined fecal samples from diarrheic calves using light microscope were positive for Eimeria species. The obtained results are higher than $12.1 \%$ [28] 40.4\% [29] and 27\% [10] reported in Egypt. However, the obtained percentage was lower than $100 \%$ reported in calves [30] and 64.9\% reported in calves by light microscope in villages of Lower Egypt [23]. 


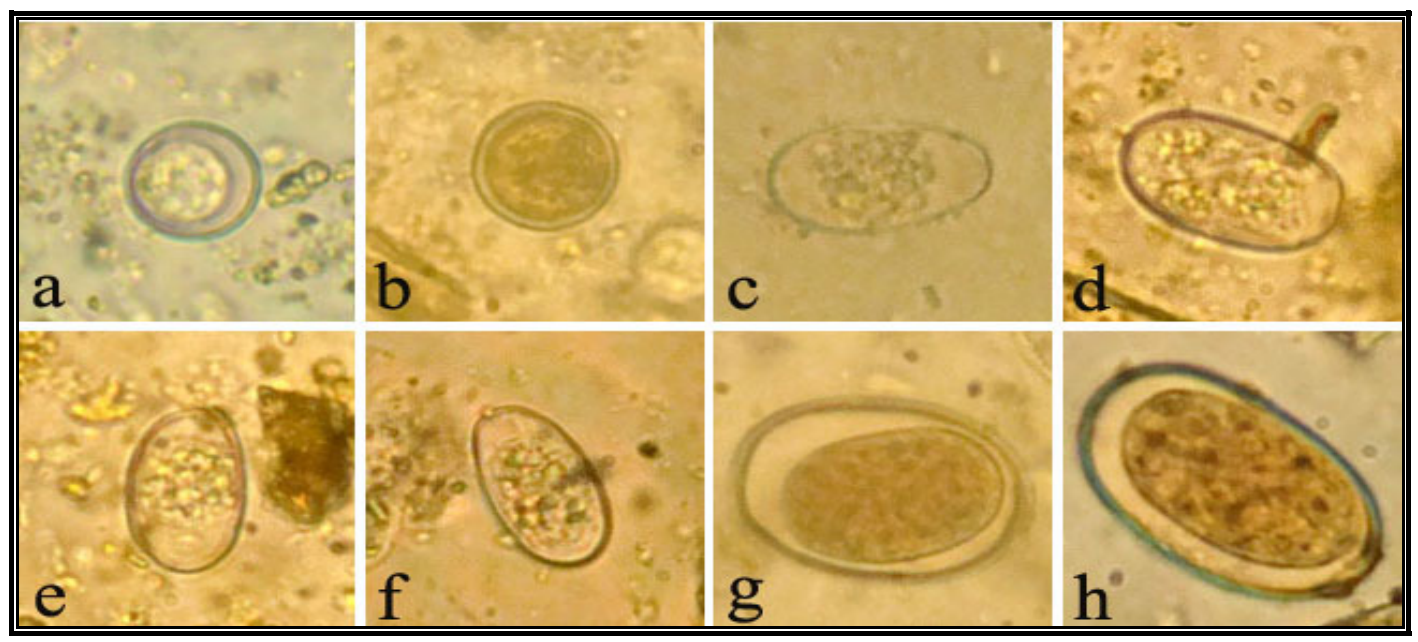

Figure 1: Unsporulated oocysts of Eimeria species in naturally infected calves a. E.subspherica, b. E. zuernii, c. E. bovis, d. E. cylindrica, e. E. alabamensis, f. E. elipsoidalis, g. E. canadinensis, h. E. auburnensis X 40.

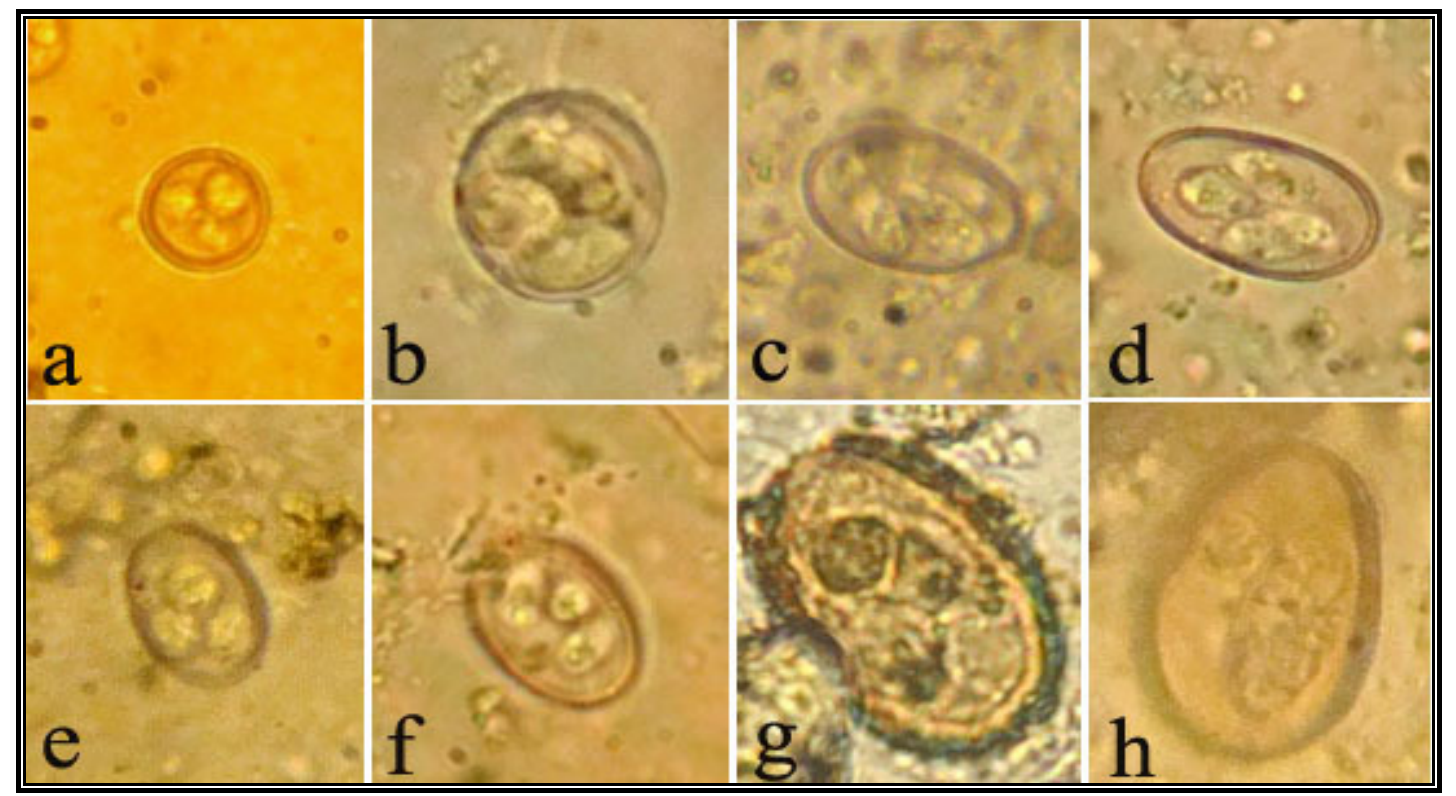

Figure 2: Sporulated oocysts of Eimeria species in naturally infected calves a. E.subspherica, b. E. zuernii, c. E. bovis, d. E. cylindrica, e. E. alabamensis, f. E. elipsoidalis, g. E. canadinensis, h. E. auburnensis X 40.

The prevalence of Eimeria infection in the existing study is comparable to that recorded in different countries $47.59 \%$ in Sudan [31] and $47.1 \%$ in Shanghai, China [32]. Our results were higher than $28.3 \%$ in Iraq [33], $31.9 \%$ in Ethiopia [15], 33.2\% of calves in India [34] and $42.7 \%$ in calves in Kenya [35], while, was lower than $60.9 \%$ in Denmark [36], $51.4 \%$ in Ethiopia [37], 54.6\% in India [38] and $96 \%$ in the central Appalachian region of the United States [39]. This variation may be attributed to the changes in environment, feeding strategies in addition to husbandry practice of the examined animals in different countries $[10,23,29]$. Concerning the age, the prevalence of Eimeria spp. was lower 28.9\% (13/45) in calves 1 week - 3 month of age, while it was higher $73.3 \%(22 / 30)$ in calves 3 -6 months of age. These results were comparable to that obtained by Ahmed and Hassan [23]. While calves less than 3 months age showed lower rate as reported by El-Seify et al. [29] who found that the most susceptible age was 3-6 months with the percentage of $37.1 \%$. Moreover, Fadly [10] mentioned that 
the prevalence of Eimeria was significantly higher $(46.6 \%)$ in 4-5 months old calves in Behera Governorate, this was also consistent with other studies $[14,25,40]$. Higher infection rate was detected in calves aged from 3 to 6 months as they discontinue a milk diet and passive immunity drops, while calves of 1 week to 3 months of age has good nursing of the colostrum feeding providing them with sufficient immunity [25,29]. Concerning the season, the prevalence of Eimeria spp. in diarrheic calves showed the highest rate in summer $(69.2 \%)$, followed by winter $(36.4 \%)$, autumn $(25 \%)$ and spring $(7.7 \%)$. These results disagreed with that of El-Seify et al. [29] who reported that winter season was the most suitable season for Eimeria spp. infection as the infection rate of Eimeria reached to $33.3 \%$ and it was followed by spring, summer and autumn where the infection rates were $29.1 \%, 27.1 \%$ and $26.6 \%$ respectively. Another study also documented higher prevalence of coccidiosis in winter $(45.3 \%)$ followed by autumn (33.3\%), spring (16\%) and summer (13.3\%) [10]. Also, higher prevalence rate of Eimeria spp. was reported in Egypt during the months of rain [41,42]. No seasonal fluctuation in the prevalence of Eimeria infection was reported [43], while higher incidence in spring and autumn than winter and summer was documented [44]. This difference may be due to the variation of samples number, localities, management system, climate variations $[10,11]$.

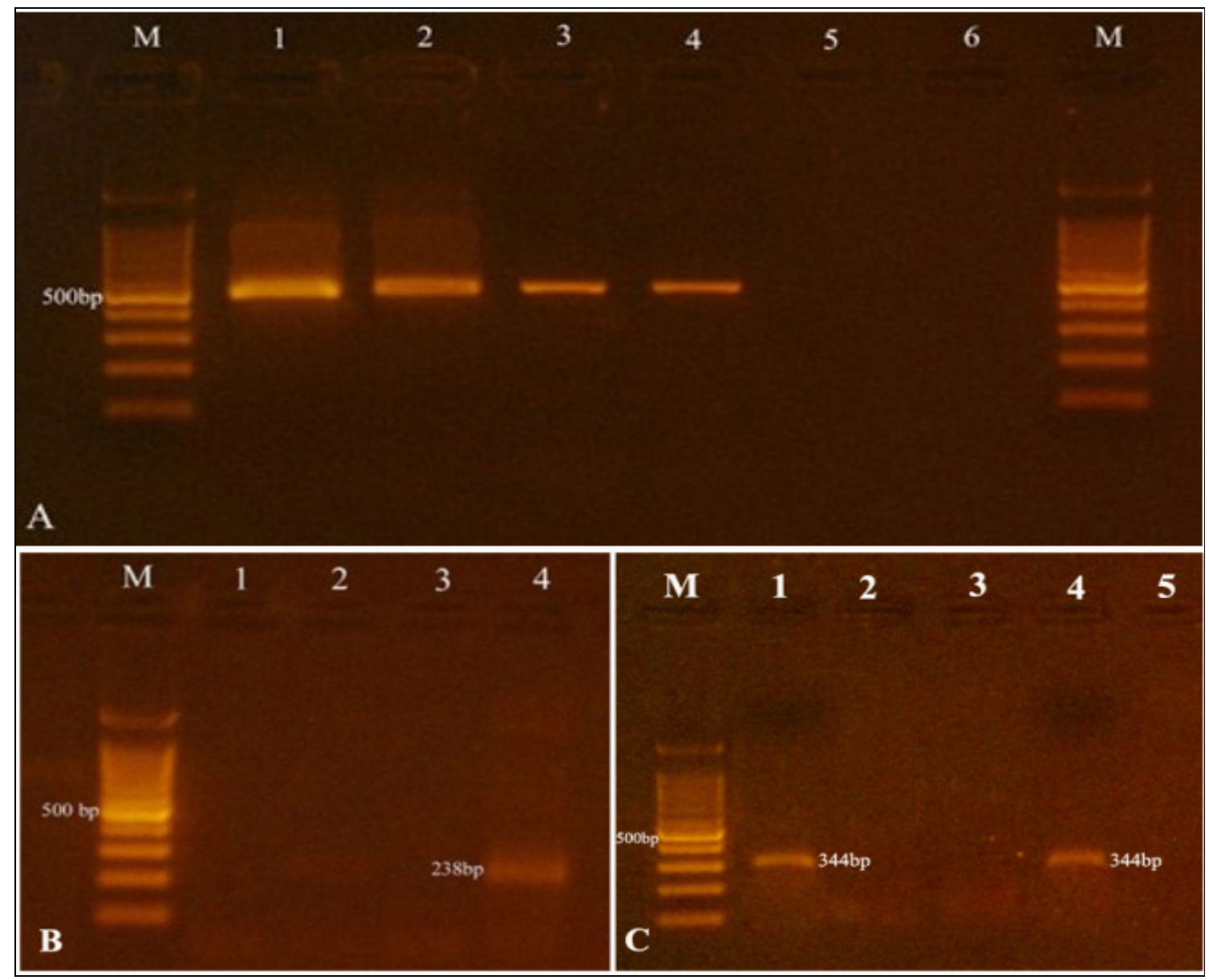

Figure 3: The electrophoresis pattern of PCR amplicon on calves fecal samples (A): using ITS, genuscommon of Eimeria primer (546 bp PCR product). M: 100bp DNA ladder; Lanes 1, 2, 3, 4: Positive samples for Eimeria; Lanes 5, 6: Negative samples. (B): using Eimeria bovis primer (238 bp PCR product). M: 100bp DNA ladder; Lane 4: Positive sample; Lanes 1, 2, 3: Negative samples for Eimeria bovis. (C): using Eimeria zuernii primers (344 bp PCR product). M: 100bp DNA ladder; Lanes 1, 4: Positive samples for Eimeria zuernii; Lanes 2, 3,5: Negative samples. 
Parasitological examination revealed that eight species of Eimeria were identified in calves. This is within the same range as reported for calves in surveys in different countries: 11 Eimeria species in cattle reported in Kafr El-Sheikh Governorate, Egypt [29], 5 species in Behera Governorate in Egypt [10], 8 species in South-Western Ethiopia [37], 7 species in India [34] and 8 species in Al-Baha Area, Saudi Arabia [11]. This difference may be due to the different localities and management system $[10,11]$.

In the present study, the most prevalent species were $E$. zuernii $(51.4 \%)$ followed by $E$. bovis (31.4\%) and E. alabamensis (31.4\%). Similar findings were recorded by Bangoura $e t$ al. [45] who investigated that E. zuernii had a greater effect on the occurrence of diarrhea than E. bovis. Moreover, Mundt et al. [46] recorded that the level and duration of excretion was considerably higher for-E. zuernii than for E. bovis. On contrary, many authors found that E. bovis was the most frequently identified species followed by $E$. zuernii [10,11,15,37,39].

Single infection of Eimeria spp. was found in $48.6 \%$ of the infected animals, whereas mixed infection involved two, three or four Eimeria spp. was observed in $51.4 \%$. This is in agreement with Ernst et al. [47] who recorded that mixed infections were found much more common than mono species infection under natural conditions. Also, similar results were recorded by El-Seify et al. [29] who reported single infection in $47.5 \%$ and mixed infection in $52.5 \%$ of the examined animals. Moreover, Yadessa et al. [37] identified single infection in $30.8 \%$ and mixed infection in $69.2 \%$ of the examined animals. On contrary, Fadly [10] found that mixed infection was observed in $11.11 \%$ of the samples.

In the present study, two negative samples by microscopical examination were positive by PCR. Also, two negative samples by microscopical examination of E. zuernii were positive by PCR and one negative sample by microscopical examination of $E$. bovis were positive by PCR. So, PCR appeared to be more sensitive than conventional fecal inspection of oocysts. This is in agreement with Kawahara et al. [22] who recorded that PCR was effective in detection of Eimeria from feces of diarrheic calves. Information of apicomplexa genomic level has been developing constantly and species determination have been displayed using PCR [48,49].

E. bovis and E. zuernii are the most common causes of clinical coccidiosis and highly pathogenic [18]. The DNA sample was used with mixed species, E. zuernii and $E$. bovis primer as species-specific primer amplified and produced single bands with the expected sizes. These results agree with Kawahara et al. [22] who stated that the ITS-1 regions are flexible corresponding with species variation, showing a pattern of low intraspecific and high inter-specific variations in the DNA sequence, thus reduces the risk of cross-reactions with different species.

\section{Conclusion}

In conclusion, the season and age of the calves were the most significant aspects connected with the possibility of infection with coccidiosis, which is a common and important cause of economical loss in calves in Assiut Governorate. PCR technique is more rapid, convenient in detection of Eimeria in calves than microscopical examination which is very labor-intensive and require skillful technique.

\section{Conflict of interest}

The author declares no conflict of interest.

\section{References}

[1] Ahmed, W.A.; Nabil, G.M.; El-Khadrawy, H.H.; Hanafi, E.M. and Abdel-Moez, S.I. (2006): Monitoring progesterone level and markers of oxidative stress in blood of buffalo-cows with impaired fertility. Egyptian J Biophys Biomed Eng, 7: 7183.

[2] Heath, S.E. (1992): Neonatal diarrhea in calves: diagnosis and investigations in problems herds. Compend Contin Educ Vet, 14: 995-1002.

[3] Ahmed, A.A. (1980): Calf scours in Egyptian buffalo-Cows. Egyptian German Seminar on the Mortality of Newly Born Calves: 19-21.

[4] England, J.J.; Williams, S. and Cuneo, P.L. (2010): Calf Scours; Cause, Prevention, Control, and Treatment. Western Beef 
Resource Committee (Cattle Producer's Library) Animal Health Section CL645

[5] Meganck, V.; Hoflack, G.; Piepers, S. and Opsomer G. (2015): Evaluation of a protocol to reduce the incidence of neonatal calf diarrhea on dairy herds. Prev Vet Med, 118(1): 64-70.

[6] Anderson, D.C.; Kress, P.D.; Bernardini, T.M.; Davis, K.C.; Boss, D.L. and Doornbos, D.E. (2003): The effect of scours on calf weaning weight. The Professional animal scientist,19(6): 399403.

[7] Ok, M.; Güler, L.; Turgut, K.; Ok, Ü.; Sen, I.; Gündüz, I.K.; Birdane, M.F. and Güzelbektes, H. (2009): The studies on the aetiology of diarrhea in neonatal calves and determination of virulence gene markers of Escherichia coli strains by multiplex PCR. Zoonoses Public Health, 56(2): 94-101.

[8] Radostits, O.M.; Gay, C.C.; Hinchcliff, K.W. and Constable, P.D. (2007): Veterinary Medicine: A Textbook of the diseases of cattle, horses, sheep, pigs and goats. $10^{\text {th }}$ Ed. B. Saunders, London, New York, Philadelphia, Sydney and Toronto, USA, pp: 1498-1506.

[9] Radostits, O.M.; Blood, D.C. and Gay, C.C. (1994): Veterinary Medicine. A Textbook of the Diseases of Cattle, Sheep, Pigs, Goats, and Horses. 8th ed. London. Philadelphia, PA: Bailliere Tindall; 1181-1199.

[10] Fadly, R.S.A. (2012): Some parasitic causes of diarrhea in calves in Behera Governorate. Assiut Vet. Med. J. 58(143): 328-334.

[11] Ibrahim, M.M.; Soliman, M.F. and Alghamdi, A.O. (2015): Subclinical Bovine Coccidiosis in Al -Baha Area, Saudi Arabia. Int J Vet Sci Res ,1(1): 23-28.

[12] Carlson, J.C.; Linz, G.M.; Ballweber, L.R.; Elmore, S.A.; Pettit, S.E. and Franklin, A.B. (2011): The role of European starlings in the spread of Coccidia within concentrated animal feeding operations. Vet Parasitol 180: 340-343.
[13] Heinrichs, A.J. and Radostits, O.M. (2001): Health and Production Management of Dairy Calves and Replacement Heifers. In: Radostits, O.M., Ed., Herd Health, Food Animal Production Medicine, W.B. Saunders Company, Philadelphia, p: 333-395.

[14] Daugschies, A. and Najdrowski, M. (2005): Eimeriosis in cattle: Current understanding. Zoonoses Public Health, 52(10): 417-427.

[15] Alemayehu, A.; Nuru, M.; Belina, T.; Mekibib, B.; Desta, T. and Tesfaye, D. (2013): Prevalence of bovine coccidia in Kombolcha district of South Wollo, Ethiopia. J Vet Med Anim Health 5(2): 41-45.

[16] Eckert, J.; Friedhoff, K.T. and Zahner, H. (2008): Lehrbuch der Parasitologie für die Tiermedizin. Stuttgart: Enke Verlag.

[17] Pandit, B.A. (2009): Prevalence of Coccidiosis in Cattle in Kashmir valley. Vet Scan, 4:16-20.

[18] Bangoura, B.; Mundt, H.C.; Schmäschke, R.; Westphal, B. and Daugschies, A. (2012): Prevalence of Eimeria bovis and Eimeria zuernii in German cattle herds and factors influencing oocyst excretion. Parasitol Res, 110(2): 875881.

[19] Ernst, J.V.; Ciordia, H. and Stuedemann, J.A. (1984): Coccidia in cows and calves on pasture in north Georgia (USA). Vet Parasitol. 15(3-4): 213-221.

[20] Svensson, C.; Uggla, A. and Pehrson, B. (1994): Eimeria alabamensis infection as a cause of diarrhoea in calves at pasture. Vet Parasitol, 53(1-2): 33-43.

[21] Long, P.L. and Joyner, L.P. (1984): Problems in the identification of species of Eimeria. $\mathrm{J}$ Eukaryot Microbiol, 31(4): 535-541.

[22] Kawahara, F.; Zhang, G.; Mingala, C.N.; Tamura, Y.; Koiwa, M.; Onuma, M. and Nunoya, T. (2010): Genetic analysis and development of speciesspecific PCR assays based on ITS-1 region of rRNA in bovine Eimeria 
parasites. Vet Parasitol, 174(1-2): 4957.

[23] Ahmed, W.M. and Hassan, S.E. (2007): Applied studies on coccidiosis in growing buffalo-calves with special reference to oxidant/antioxidant status. World J Zool, 2 (2): 40-48.

[24] Soulsby, E.J.L. (1982): Helminths, Arthropods, and Protozoa of Domestic Animals. $7^{\text {th }}$ Ed., Bailliere, Tindall and Cassell, London, pp. 594-664.

[25] Lassen, B.; Viltrop, A.; Raaperi, K. and Järvis, T. (2009): Eimeria and Cryptosporidium in Estonian dairy farms in regard to age, species, and diarrhea. Vet Parasitol, 166(3-4): 212219.

[26] Fisher, R.A. and Yates, F. (1963): Statistical Tables for biological agricultural and medical Research. 6th ed., Table IV, Oliver \& Boyd, Ltd., Edinburgh, by permission of the authors and publishers.

[27] Thomas, H.S. (1994): Coccidiosis in calves. The Cattleman, 81(5): 21-32.

[28] El Sherif, A.M.; Abdel-Gawad, M.A.; Lotfy, H.S. and Shokier, K.A. (2000): Impact of gastrointestinal nematodes and some enteric protozoal affections on the health of buffalo calves. Egyptian J Agric Res, 78(1):127-135

[29] El-Seify, M.A.; Desoukey, M.A.; Khalafalla, R.E. and Sorour, S.Sh. (2012): Prevalence of Eimeria and Cryptosporidium species in cattle in Kafr El-Sheikh Province. Kafrelsheikh Vet Med J, 10(2): 1-22.

[30] Abdel-Aal, A.A. (1981): Studies on Eimeria sp. infecting cattle and buffalo calves in Egypt and the effect of some anticoccidial drugs. M.V.Sc. Thesis (Parasitology), Cairo Univ., Egypt.

[31] Gasmir, G.S.; Osman, A.Y.; El-Amin, F.A. and Halima, L.O. (2011): A survey of enteric Coccidia of cattle in the Sudan. Sudan J Vet Res, 15: 43-48.

[32] Dong, H.; Zhao, Q.; Han, H.; Jiang, L.; Zhu, S.; Li, T.; Kong, C. and Huang, B. (2012): Prevalence of coccidial infection in dairy cattle in Shanghai, China. J Parasitol. 98(5):963-966.

[33] Hasan, M.H.; Butty, E.T. and Al-Taee, A.F. (2010): A study on intestinal protozoa in calves in Ninevah Governorate. Iraq J Vet Sci, 24(2):163167.

[34] Das, M.; Deka, D.K.; Sarmah, P.C.; Islam, S. and Sarma, S. (2015): Diversity of Eimeria spp. in dairy cattle of Guwahati, Assam, India. Vet. World, 8(8): 941-945.

[35] Peter, G.S.; Gitau, G.K.; Mulei, C.M.; Vanleeuwen, J.; Richards, S.; Wichtel, J.; Uehlinger, F. and Mainga, O. (2015): Prevalence of Cryptosporidia, Eimeria, Giardia, and Strongyloides in pre-weaned calves on small holder dairy farms in Mukurweini district, Kenya. Vet World, 8(9):1118-1125.

[36] Enemark, H.L.; Dahl, J. and Enemark, J.M. (2013): Eimeriosis in Danish dairy calves-correlation between species, oocyst excretion and diarrhea. Parasitol Res, 112(1):169-176.

[37] Yadessa, T.K.; Awash, H.D. and Gurmu, G.K. (2014): Prevalence of calves coccidiosis in Jimma town dairy farms, South-Western Ethiopia. Sci J Zool, 3(4):36-44.

[38] Singh, N.K. and Juyal, P.D. (2014): Prevalence of gastrointestinal parasites in buffalo calves from different agroclimatic zones of Punjab. J Parasit Dis, 38(4):367-370.

[39] Lucas, A.S.; Swecker, W.S.; Lindsay, D.S.; Scaglia, G.; Neel, J.P.; Elvinger, F.C. and Zajac, A.M. (2014): A study of the level and dynamics of Eimeria populations in naturally infected, grazing beef cattle at various stages of production in the Mid-Atlantic USA. Vet Parasitol, 202 (3-4):201-206.

[40] Abebe, R.; Wossene, A. and Kumsa, B. (2008): Epidemiology of Eimeria infections in calves in Addis Ababa and Debre Zeit dairy farms, Ethiopia. Int $\mathbf{J}$ Appl Res Vet Med, 6(1): 24-30. 
[41] El-Sherif, A.M. and Aboel-Hadid, S.M. (2005): Epizootological investigation about different internal parasitic affections among cattle calves in Benisuif Governorate. J Egypt Vet Med Asso 65 (6) 261-274.

[42] Mary, B. (2003): Anticoccidial effects of clindamycin and chloramphenicol on bovine Eimeria. EVMSPJ, 1: 13-27.

[43] Vercrysee, J. (1982): The Coccidia of sheep and goats in Senegal. Vet Parasitol, 10(4): 297-306.

[44] Sánchez, R.O.; Romero, J.R. and Founroge, R.O. (2008): Dynamics of Eimeria oocyst excretion in dairy calves in the province of Buenos Aire (Argentina), during their first 2 months of age. Vet Parasitol, 151(2-4): 133138.

[45] Bangoura, B.; Mundt, H.C.; Schmäschke, R.; Westphal, B. and Daugschies, A. (2011): Prevalence of Eimeria bovis and Eimeria zuernii in German cattle herds and factors influencing oocyst excretion. Parasitol Res, 109 (1): 12938.
[46] Mundt, H.-C. Bangoura, B. Mengel, H. Keidel, J. Daugschies A. (2005): Control of clinical coccidiosis of calves due to Eimeria bovis and Eimeria zuernii with toltrazuril under field conditions. Parasitol Res, 97(1): S134S142

[47] Ernst, J.V.; Stewart, T.B. and Witlock, D.R. (1987): Quantitative determination of coccidian oocysts in beef calves from the coastal plain area of Georgia (USA). Vet Parasitol, 23(12): $1-10$.

[48] Müller, N.; Zimmermann, V.; Hentrich, B. and Gottstein, B. (1996): Diagnosis of Neospora caninum and Toxoplasma gondii infection by PCR and DNA hybridization immunoassay. $\mathrm{J}$ Clin Microbiol, 34(11): 2850-2852.

[49] Tsuji, N.; Kawazu, S.; Ohta, M.; Kamio, T.; Isobe, T.; Shimura, K. and Fujisaki, K., (1997): Discrimination of eight chicken Eimeria species using the twostep polymerase chain reaction. J Parasitol, 83(5): 966-970

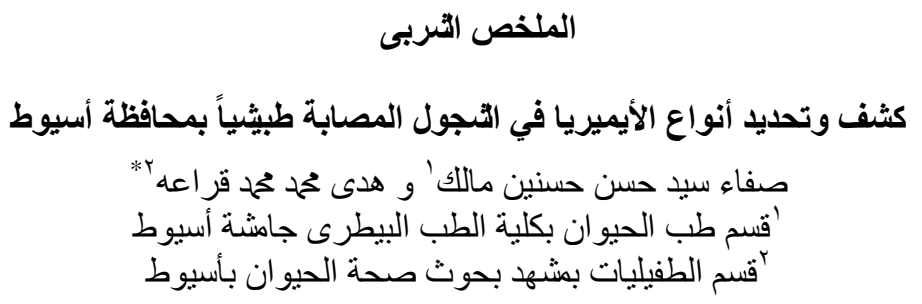

أجريت هذه الدر اسة لمثرفة مدى انتشارطفيل الأيميريا فى عدد V0 من الثجول المصابة بالإسهال في محافظة أسيوط.

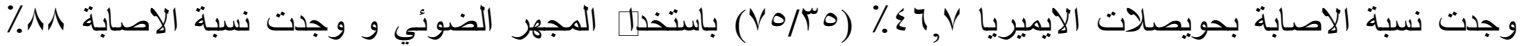

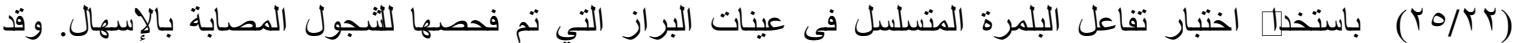

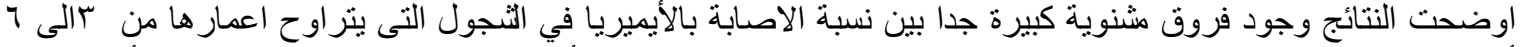

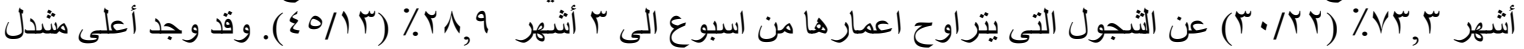

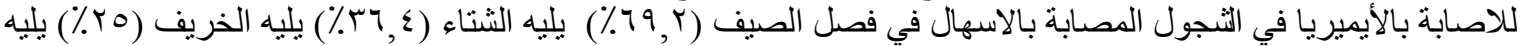

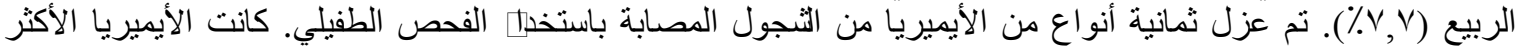

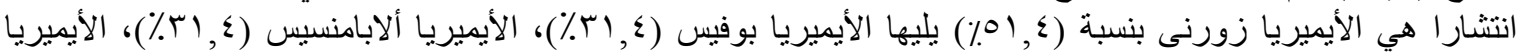

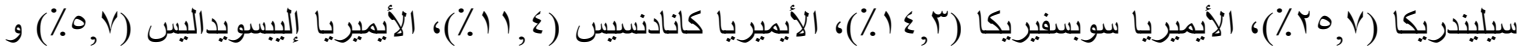

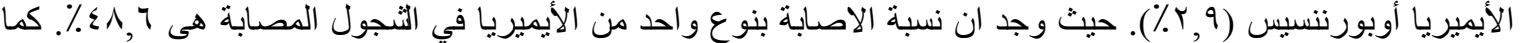

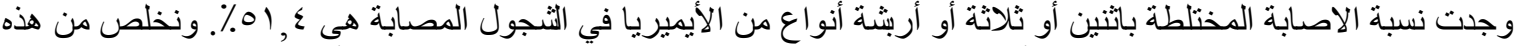

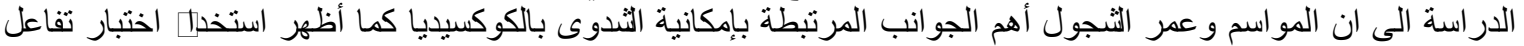

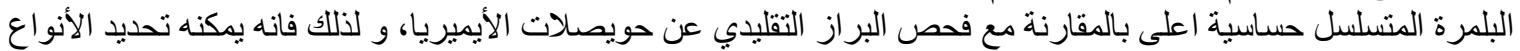

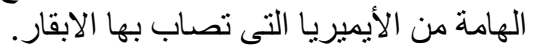

